\title{
Analysis of the Impact of Government Planning Policy on the Development of Green Industry
}

\author{
Jiao Jianling ${ }^{\mathrm{a},}$, Li Huili' ${ }^{\mathrm{b}}$, Hu Dianxi ${ }^{\mathrm{c}}$, \\ School of Management, Hefei University of Technology, Tunxi Road, Anhui Hefei 230009, China

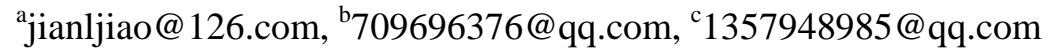

Keywords: green industry, panel data model, national planning policy, local planning policy.

\begin{abstract}
The government planning policy is an important driving force for the development of China's green industry. Therefore, this article selected three industries with higher greenness in the national economy industry: forestry, wood processing, and wood, bamboo, rattan, brown and grass product industry, and renewable resource recycling industry as research subjects. Based on the panel data of China provinces and cities from 2003 to 2015, an empirical test of the national and local planning policy for the development of these three green industries was conducted by constructing a panel model. The study found that compared with national planning policy, local planning policy had a relatively significant impact on the development of green industry; the combined effects of national planning policy and local planning policy had significant differences in the impact on green industry sectors; the joint effects of renewable resource recycling industry was significant, and the joint effects of the forestry and wood processing industry were not significant. Overall, the government planning policy had a heterogeneous effect on the promotion of three green industry sectors. The renewable resource recycling industry had the most significant effects, followed by forestry, wood processing, and wood, bamboo, rattan, brown and grass products.
\end{abstract}

\section{Introduction}

According to the BP World Energy Statistics Yearbook, China has become the largest energy consumer and carbon dioxide emitter. As of 2017, China's total energy consumption has reached 4.475 billion tons of standard coal (3.1322 billion tons of oil equivalent), and the total carbon dioxide emissions has reached 9.233 billion tons ${ }^{[1]}$. In 2016, the second UN Environment Conference focused on green sustainable development, and the Chinese government also actively promoted the concept of green development. However, China has always been a traditional high-consumption, high-pollution industry production model. Therefore, vigorously developing green industry is an effective way to deal with energy and environmental issues.

From foreign studies, the European and US governments had assessed the impact of policies on green industry, but the results were mixed. For example, some scholars believed that the renewable resource policy (hereinafter referred to as the RPS policy) was one of important driving forces for green enterprises in the United States, and had positive impact on the development of green industry ${ }^{[2-3]}$; but Frontel pointed out that the German RPS policy brought high costs and had no positive impact on energy security or emission reduction ${ }^{[4]}$. In contrast, domestic scholars had described the green industry more qualitatively. They have begun to empirically study the green industry recent years. Chi constructed a green industry evaluation index system involving green

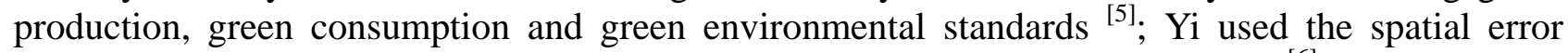
model to explore the driving factors of regional differences in green economy ${ }^{[6]}$. But related to green industry and government planning policy, domestic scholars were less involved.

According to the United Nations Industrial Development Organization, "the production and development of green industry does not sacrifice the health of natural systems or bring adverse health consequences to human beings." In the industrial system, two aspects are involved: one is to "green" the existing industrial sector, the second is to create new green industry sectors. The article selected the existing sector of "greening" with higher greenness: forestry, wood processing and 
wood, bamboo, rattan, palm, grass products and renewable resource recycling industry as research objects ${ }^{[7]}$, based on the panel data of provinces and cities from 2003 to 2015, we focused on the influencing factors of China's green industry development from the perspective of government policy, paid attention to the role of national planning policy and local planning policy in the development of green industry, and further examined the impact of national policy through local policy.

\section{Research design}

\subsection{Variable selection and data source}

Considering the availability of data, the sample unit of forestry was 31 provinces in mainland China, and the wood processing and wood, bamboo, rattan, palm and grass products industry was excluded from 30 provinces of Qinghai, the renewable resource industry was to eliminate 28 provinces outside Tibet, Qinghai and Xinjiang. The dependent variable was per capita output value of green industry. The output value data was derived from the Chinese Statistical Yearbook and the local statistical yearbook. The independent variable indicators were government planning policy, development potential, market size, labor input, urbanization and regions.

The government planning policy was to quantify policy indicators from national and local perspective. Firstly, from the national level, the implementation year dummy variables of the "Eleventh Five-Year Plan" $\left(N P_{1}\right)$ and the "Twelfth Five-Year Plan" ( $\left.N P_{2}\right)$ were used to measure the effectiveness of national planning policy. Secondly, from the local perspective, by manually sorting out local five-year plans, collecting and summarizing whether there were specific and quantifiable targets in local industrial policies $(L P)$ to measure the differences in local government's emphasis on green industry. Finally, considering national policy had a path dependence on local policy, introducing two cross-variables, that is to construct the interaction between national planning policy and local planning policy, and enhance the robustness of government planning policy research results.

Development potential selected R\&D intensity $(R$ )as an indicator, the calculation formula was $R \& D$ expenditure internal expenditure/regional GDP, and the $R \& D$ expenditure internal expenditure data was derived from the China Science and Technology Statistical Yearbook. The market size was to convert per capita GDP ( $P G$ ) into a constant price in 2005, and used the data that was one year behind to solve the endogenous problem. The labor input selected the number of employees in each department (EMP) as an indicator, and the data came from the China Labor Statistics Yearbook. The raw data to measure urbanization came from the China Statistical Yearbook. The research units were integrated into eight regions: Northeast region (Heilongjiang, Jilin, Liaoning), Beijing-Tianjin region (Beijing, Tianjin), northern coast (Hebei, Shandong), eastern coast (Shanghai, Jiangsu, Zhejiang), southern coast (Fujian, Guangdong, Hainan), Central region (Shanxi, Henan, Anhui, Hubei, Hunan, Jiangxi), Northwest region (Inner Mongolia, Shanxi, Ningxia, Gansu, Qinghai, Xinjiang), Southwest region (Sichuan, Chongqing, Guangxi, Yunnan, Guizhou, Tibet).

\subsection{Research method}

Based on Hausman results, the study selected a random effects model. The random effects model considers the heteroscedasticity problem to a certain extent, and the generalized least squares (GLS) method can solve the sequence correlation problem. Therefore, the GLS estimation was used in this paper. In order to obtain a more robust estimation result, the maximum likelihood estimation (MLE) was also used, and the basic regression estimation results was shown in Table 3. The research model was constructed as follows:

$$
\begin{aligned}
P C O V_{i, t}= & C+\beta_{1} N P_{1_{i, t}}+\beta_{2} N P_{2_{i, t}}+\beta_{3} L P_{i, t}+\beta_{4}\left(N P_{i_{i, t}} \times L P_{i, t}\right)+\beta_{5}\left(N P_{2_{i, t}} \times L P_{i, t}\right) \\
& +\beta_{6} R_{i, t}+\beta_{7} P G_{i, t-1}+\beta_{8} E M P_{i, t}+\beta_{9} U R_{i, t}+\sum A R E A+v_{i}+e_{i, t}
\end{aligned}
$$


Among them, ${ }^{P C O V_{i t}}$ was the per capita output value of the green industry; ${ }^{C}$ was a constant term; ${ }^{N P_{14}}$, ${ }^{N P_{2}}$, were "Eleventh Five-Year Plan" and "Twelfth Five-Year Plan" in the national planning policy; ${ }^{L P_{t, t}}, R_{t, t},{ } M P_{t, t}, U R_{t, t}$ were the local specific policy objectives, R\&D intensity, the number of employees and the rate of urbanization; $P_{G_{t, k-1}}$ was the per capita GDP of the province; AREA was the regional variable; $v_{i}$ was the random effect term; $e_{i, t}$ was the error term.

\section{Empirical research}

\subsection{Green industry development policy}

Table 1 National planning policy for green industry development

\begin{tabular}{|c|c|c|}
\hline Green Industry & “Eleventh Five-Year” Plan & “Twelfth Five-Year” Plan \\
\hline Forestry & $\begin{array}{l}\text { Three-step strategy, medium and } \\
\text { long-term goals; By 2010, forest } \\
\text { coverage will reach } 20 \% \text { and forest } \\
\text { stocks will reach } 13.2 \text { billion cubic } \\
\text { meters }\end{array}$ & $\begin{array}{l}\text { Advance the "Eleventh Five-Year" } \\
\text { development strategy. By } 2015 \text {, the forest } \\
\text { coverage rate will reach } 21.66 \% \text { and the } \\
\text { forest stock volume will reach } 14.3 \\
\text { billion cubic meters }\end{array}$ \\
\hline $\begin{array}{l}\text { Wood } \\
\text { processing and } \\
\text { wood, bamboo, } \\
\text { rattan, brown, } \\
\text { grass products } \\
\text { industry }\end{array}$ & $\begin{array}{l}\text { By 2010, the annual output of } \\
\text { commercial materials will reach } \\
99.8 \text { million cubic meters, and the } \\
\text { supply rate of commercial forest } \\
\text { products will reach } 70 \% \text {; the } \\
\text { construction of timber forest base } \\
\text { projects, bamboo industry and other } \\
\text { industrial systems }\end{array}$ & $\begin{array}{l}\text { By 2015, the annual output of commercial } \\
\text { materials will reach } 100 \text { million cubic } \\
\text { meters, and the supply rate of commercial } \\
\text { forest products will reach } 70 \% \text {; the } \\
\text { construction of timber strategic reserve } \\
\text { production base }\end{array}$ \\
\hline $\begin{array}{l}\text { Renewable } \\
\text { resource } \\
\text { recycling } \\
\text { industry }\end{array}$ & $\begin{array}{l}\text { Carry out demonstration projects } \\
\text { for circular economy } \\
\text { demonstration; by 2010, the } \\
\text { comprehensive utilization rate of } \\
\text { industrial solid waste will reach } \\
60 \%\end{array}$ & $\begin{array}{l}\text { Construction and transformation of } \\
\text { various industrial parks, and deepening } \\
\text { the demonstration of circular economy; } \\
\text { by } 2015 \text {, the comprehensive utilization } \\
\text { rate of industrial solid waste will reach } \\
72 \%\end{array}$ \\
\hline
\end{tabular}

\subsection{Local planning policy}

Table 2 Local planning policy for green industry development

\begin{tabular}{|c|c|c|}
\hline Green industry & “Eleventh Five-Year” Plan & “Twelfth Five-Year” Plan \\
\hline Forestry & $\begin{array}{l}\text { The forest coverage targets in Shanxi, } \\
\text { Tibet, Gansu, Qinghai, Ningxia and } \\
\text { Xinjiang are lower than the national } \\
\text { target of } 20 \% \text {, and the local forest } \\
\text { coverage targets are not completed in } \\
\text { Jilin, Heilongjiang, Guangdong, } \\
\text { Yunnan, Gansu and Ningxia }\end{array}$ & $\begin{array}{l}\text { The forest coverage targets in } \\
\text { Shanghai, Tibet, Gansu, Qinghai, } \\
\text { Ningxia and Xinjiang are lower than } \\
\text { the national target of } 20 \% \text {, and the } \\
\text { local forest coverage targets are not } \\
\text { completed in Tibet, Inner Mongolia, } \\
\text { Liaoning and Ningxia }\end{array}$ \\
\hline $\begin{array}{l}\text { Wood processing } \\
\text { and wood, } \\
\text { bamboo, rattan, } \\
\text { brown, grass } \\
\text { products industry }\end{array}$ & $\begin{array}{l}\text { Jilin, Jiangxi, and Sichuan established } \\
\text { development scales for forestry } \\
\text { projects, industrial raw material } \\
\text { forests, and bamboo forest production } \\
\text { bases respectively }\end{array}$ & $\begin{array}{l}\text { On the basis of the "Eleventh } \\
\text { Five-Year Plan", Fujian and Guangxi } \\
\text { also established the scale of } \\
\text { development of forestry and bamboo } \\
\text { forest production bases }\end{array}$ \\
\hline
\end{tabular}


Renewable resource recycling industry
The comprehensive utilization rate of industrial solid waste in all regions almost exceeds the national target of $60 \%$, and most of them have completed the target as planned or exceeded
Compared with the "Eleventh Five-Year Plan” period, more local targets exceeded the national target by $72 \%$. The policy situation in other places is basically the same as that in the "Eleventh Five-Year Plan" period

\subsection{Analysis and discussion of results}

Table 3 Basic regression results

\begin{tabular}{|c|c|c|c|c|c|c|}
\hline \multirow[t]{2}{*}{ variable } & \multicolumn{3}{|c|}{ GLS estimate } & \multicolumn{3}{|c|}{ MLE estimate } \\
\hline & (1) & $(2)$ & (3) & (1) & $(2)$ & (3) \\
\hline$N P_{1}$ & $\begin{array}{c}-0.10 \\
(-0.69)\end{array}$ & $\begin{array}{c}-0.18 \\
(-1.57)\end{array}$ & $\begin{array}{c}-0.18 \\
(-0.69)\end{array}$ & $\begin{array}{c}-0.10 \\
(-0.69)\end{array}$ & $\begin{array}{c}-0.17 \\
(-1.51)\end{array}$ & $\begin{array}{c}-0.18 \\
(-0.69)\end{array}$ \\
\hline$N P_{2}$ & $\begin{array}{l}0.29 * \\
(1.92)\end{array}$ & $\begin{array}{c}-0.66 \\
(-1.46)\end{array}$ & $\begin{array}{c}-0.45 \\
(-1.50)\end{array}$ & $\begin{array}{l}0.30 * * \\
(1.97)\end{array}$ & $\begin{array}{c}-0.65 \\
(-1.47)\end{array}$ & $\begin{array}{c}-0.44 \\
(-1.53)\end{array}$ \\
\hline$L P$ & $0.0018(0.01)$ & $\begin{array}{c}-0.1579 \\
(-1.38)\end{array}$ & $\begin{array}{c}0.7301^{* * *} \\
(3.72)\end{array}$ & $\begin{array}{l}0.0002 \\
(0.00)\end{array}$ & $\begin{array}{l}-0.1554 \\
(-1.38)\end{array}$ & $\begin{array}{c}0.7327 * * * \\
(3.81)\end{array}$ \\
\hline$N P_{1} \times L P$ & $\begin{array}{l}-0.31^{*} \\
(-1.87)\end{array}$ & $\begin{array}{c}0.26 \\
(1.57)\end{array}$ & $\begin{array}{l}0.47 * * \\
(2.14)\end{array}$ & $\begin{array}{l}-0.31^{*} \\
(-1.87)\end{array}$ & $\begin{array}{c}0.26 \\
(1.59)\end{array}$ & $\begin{array}{l}0.47 * * \\
(2.20)\end{array}$ \\
\hline$N P_{2} \times L P$ & $\begin{array}{l}-0.011 \\
(-0.07)\end{array}$ & $\begin{array}{c}0.370 * * \\
(2.40)\end{array}$ & $\begin{array}{l}0.620^{*} \\
(1.78)\end{array}$ & $\begin{array}{l}-0.008 \\
(-0.05)\end{array}$ & $\begin{array}{c}0.374^{* *} \\
(2.45)\end{array}$ & $\begin{array}{l}0.629 * \\
(1.84)\end{array}$ \\
\hline$R$ & $\begin{array}{c}-0.08 \\
(-1.02)\end{array}$ & $\begin{array}{c}-0.14 \\
(-1.03)\end{array}$ & $\begin{array}{c}-0.23 \\
(-0.95)\end{array}$ & $\begin{array}{c}-0.08 \\
(-1.09)\end{array}$ & $\begin{array}{c}-0.13 \\
(-1.06)\end{array}$ & $\begin{array}{c}-0.23 \\
(-0.98)\end{array}$ \\
\hline$P G$ & $\begin{array}{c}0.46^{* * *} \\
(3.57) \\
\end{array}$ & $\begin{array}{c}2.69 * * * \\
(11.5) \\
\end{array}$ & $\begin{array}{c}3.05^{* * * *} \\
(7.32) \\
\end{array}$ & $\begin{array}{c}0.47 * * * \\
(3.69) \\
\end{array}$ & $\begin{array}{c}2.66^{* * *} \\
(11.72) \\
\end{array}$ & $\begin{array}{c}3.05^{* * *} \\
(7.49)\end{array}$ \\
\hline EMP & $\begin{array}{l}0.004 \\
(0.34)\end{array}$ & $\begin{array}{c}0.427 * * * \\
(7.18)\end{array}$ & $\begin{array}{l}0.002 \\
(0.04)\end{array}$ & $\begin{array}{l}0.006 \\
(0.55)\end{array}$ & $\begin{array}{c}0.445^{* * *} \\
(7.69)\end{array}$ & $\begin{array}{l}0.004 \\
(0.09)\end{array}$ \\
\hline$U R$ & $\begin{array}{c}0.45 \\
(1.28) \\
\end{array}$ & $\begin{array}{c}-0.85 \\
(-1.37) \\
\end{array}$ & $\begin{array}{c}0.07 \\
(0.07) \\
\end{array}$ & $\begin{array}{c}0.41 \\
(1.20) \\
\end{array}$ & $\begin{array}{c}-0.83 \\
(-1.42)\end{array}$ & $\begin{array}{c}0.02 \\
(0.02) \\
\end{array}$ \\
\hline $\begin{array}{l}\text { Northeast } \\
\text { region }\end{array}$ & $\begin{array}{c}1.81^{* * *} \\
(2.85)\end{array}$ & $\begin{array}{l}1.73 * * \\
(2.10)\end{array}$ & $\begin{array}{c}0.05 \\
(0.05)\end{array}$ & $\begin{array}{c}1.77 * * * \\
(3.20)\end{array}$ & $\begin{array}{l}1.68 * * \\
(2.46)\end{array}$ & $\begin{array}{c}0.06 \\
(0.07)\end{array}$ \\
\hline $\begin{array}{l}\text { Beijing-Tianjin } \\
\text { area }\end{array}$ & & & $\begin{array}{l}1.49 * \\
(1.68)\end{array}$ & & & $\begin{array}{l}1.49 * \\
(1.80)\end{array}$ \\
\hline Northern coast & $\begin{array}{c}1.05 \\
(1.53)\end{array}$ & $\begin{array}{c}0.92 \\
(1.16)\end{array}$ & & $\begin{array}{c}1.03 \\
(1.54)\end{array}$ & $\begin{array}{c}0.89 \\
(1.39)\end{array}$ & \\
\hline Eastern coast & $\begin{array}{c}0.74 \\
(1.20)\end{array}$ & $\begin{array}{l}1.59 * \\
(1.75)\end{array}$ & $\begin{array}{c}0.54 \\
(0.54)\end{array}$ & $\begin{array}{c}0.73 \\
(1.37)\end{array}$ & $\begin{array}{l}1.58 * * \\
(2.10)\end{array}$ & $\begin{array}{c}0.55 \\
(0.60)\end{array}$ \\
\hline Southern coast & $\begin{array}{c}2.36 * * * \\
(3.77)\end{array}$ & $\begin{array}{c}1.17 \\
(1.43)\end{array}$ & $\begin{array}{c}0.68 \\
(0.69)\end{array}$ & $\begin{array}{c}2.33^{* * * *} \\
(4.31)\end{array}$ & $\begin{array}{c}1.14 \\
(1.60)\end{array}$ & $\begin{array}{c}0.69 \\
(0.76)\end{array}$ \\
\hline Central Region & $\begin{array}{c}1.92 * * * \\
(3.37)\end{array}$ & $\begin{array}{l}1.77 * * \\
(2.27)\end{array}$ & $\begin{array}{l}1.49^{*} \\
(1.72)\end{array}$ & $\begin{array}{c}1.90 * * * \\
(3.83)\end{array}$ & $\begin{array}{c}1.75^{* * * *} \\
(2.67)\end{array}$ & $\begin{array}{l}1.48^{*} \\
(1.85)\end{array}$ \\
\hline $\begin{array}{l}\text { Northwest } \\
\text { region }\end{array}$ & $\begin{array}{l}1.44^{* *} \\
(2.51)\end{array}$ & $\begin{array}{c}0.53 \\
(0.67)\end{array}$ & $\begin{array}{c}-0.37 \\
(-0.40)\end{array}$ & $\begin{array}{c}1.41 * * * \\
(2.84)\end{array}$ & $\begin{array}{c}0.54 \\
(0.82)\end{array}$ & $\begin{array}{c}-0.37 \\
(-0.43)\end{array}$ \\
\hline $\begin{array}{l}\text { Southwest } \\
\text { region }\end{array}$ & $\begin{array}{c}2.01^{* * * *} \\
(3.44)\end{array}$ & $\begin{array}{l}1.45^{*} \\
(1.77)\end{array}$ & $\begin{array}{c}-0.51 \\
(-0.44)\end{array}$ & $\begin{array}{c}1.98 * * * \\
(3.86)\end{array}$ & $\begin{array}{l}1.43 * * \\
(2.05)\end{array}$ & $\begin{array}{c}-0.48 \\
(-0.44)\end{array}$ \\
\hline obs & 403 & 390 & 364 & 403 & 390 & 364 \\
\hline groups & 31 & 30 & 28 & 31 & 30 & 28 \\
\hline $\mathrm{R}^{2}$ & 0.38 & 0.79 & 0.56 & & & \\
\hline $\mathrm{F}$ & $278.17 * * *$ & 938.69*** & $1015.94^{* * *}$ & $218.20 * * *$ & $492.47 * * *$ & $493.04 * * *$ \\
\hline
\end{tabular}

Note: $* * *, * *$, and $*$ indicate significant levels at $1 \%, 5 \%$, and $10 \%$ respectively. (1), (2), and (3) indicate forestry, wood processing, and wood, bamboo, rattan, and brown, grass products industry and renewable 
resource recycling industry respectively.

There were differences in the impact of national planning policy and local planning policy on green industry. At the national level, only the "Twelfth Five-Year Plan” of forestry had a promotion effect at the $10 \%$ level. The local planning policy had a positive impact on renewable resource recycling industry at the $1 \%$ level. Due to the large forest area, Heilongjiang, Yunnan, Tibet and Jilin had not complete local target targets. Moreover, the local policy of only five provinces had established the specific scale of development of the wood processing industry, other local governments had not paid enough attention to it. As a result, the local planning policy of forestry and wood processing industry had little impact on industrial development.

Due to the implementation of national planning policy in more places during the "Twelfth Five-Year Plan” period, and more production bases had been built according to local conditions. Therefore, the empirical evidence showed that the intersection of "Twelfth Five-Year Plan" and local policy of the wood processing industry had a positive effect at the $5 \%$ level. The crossover of “Twelfth Five-Year Plan” and local planning policy of forestry had a significant negative impact at the $10 \%$ level, mainly due to the unfinished planning targets of local provinces and cities that account for 38\% of the national forest area, weakening the impact of planning policy. In addition, the national "Eleventh Five-Year Plan" and "Twelfth Five-Year Plan" had played a significant role in promoting the development of renewable resource industry with the help of local policy.

Since the green industry in this paper is not the technology-intensive industry, and the urbanization process is accelerating, it will increase the industry's demand for resources and energy, and generate uncertainty about the impact of green development. Therefore, the statistical impact of R\&D intensity and urbanization was not significant. Per capita GDP had a significant boost to the green industry at the $1 \%$ level. In contrast, the renewable resource industry was more sensitive to this variable. Per capita GDP increase by 1\%, and its per capita output will increase by 3.05\%. Due to the cultivation and management of forestry and the processing and production of renewable resource industry, the quality and education requirements of the labor force are relatively high, so that the statistical impact of the number of employees was not obvious. The wood processing industry is a labor-intensive industry that relies on labor resources in production and processing. Every $1 \%$ increase in the number of employees, the per capita output will increase by $0.427 \%$. The statistical impact of the region on development of green industry was not the same. There was a certain similarity between forestry and wood processing industry and the development of most areas of the recycling industry was not obvious.

\section{Conclusions and recommendations}

The main findings of this paper are as follows:

First, there were differences in the extent to which national planning policy and local planning policy affect the development of green industry. The effects of separate national and local planning policy on the development of green industry were not ideal. The national "Twelfth Five-Year Plan" policy played a certain role in promoting the development of forestry, and local planning policy had a significant role in promoting the renewable resource recycling industry. Second, the national planning policy with the help of local planning policy on green industry had a significant effect and there was heterogeneity between industries. Among them, the effect during the "Eleventh Five-Year Plan" period was not obvious. The combination of the two during the "Twelfth Five-Year Plan" period can effectively promote the wood processing industry and the renewable resources industry.

Based on the above conclusions, the recommendations are as follows:

First, the central government can coordinate goals and tasks of each stage to facilitate the integration of regional and overall planning. Local governments need to combine regional forestry practices and adapt local conditions to flexibly formulate local planning policy. Second, the central government can continue to encourage the development of plantations, accelerate the construction of local timber reserve bases, and continuously enhance the effective supply of timber. Local governments need to pay attention to industrial development and guide the regional planning. Third, the central government can promote the construction and transformation of circular economy 
demonstrations, strengthen policy and technical support. Local governments need to continuously optimize industrial parks, strengthen basic capacity building, and enhance industrial competitiveness.

\section{References}

[1] BP. (2018) BP World Energy Statistics Yearbook. BP.

[2] Bowen W M, Park S, Elvery J A. (2013) Empirical Estimates of the Influence of Renewable Energy Portfolio Standards on the Green Economies of States. Economic Development Quarterly, 27(4):338-351.

[3] Yi H. (2014) Green businesses in a clean energy economy: Analyzing drivers of green business growth in U.S. states. Energy, 68(8):922-929.

[4] Frondel M, Ritter N, Schmidt C M. (2010) Economic impacts from the promotion of renewable energy technologies: The German experience. Energy Policy, 38(8):4048-4056.

[5] Zhou Ying, Chi Guotai. (2016) Construction Model and Empirical Study of Green Industry Evaluation Index System Based on Factor Analysis. Journal of Systems Management, 25(2):338-352.

[6] Yi H, Liu Y. (2015) Green economy in China: Regional variations and policy drivers. Global Environmental Change, 31:11-19.

[7] Chen W, Xu D, Chen J. (2017) Assessment of the practices and contributions of China's green industry to the socio-economic development. Journal of Cleaner Production, 153:648-656. 